\title{
In vitro and In vivo Anti-Arthritic Activity of Combined Ethanolic Extracts of Pisonia grandis and Cardiospermum halicacabum in Wistar Rats
}

\author{
Nandhini Padmini, Shobana Devi Sundaramoorthy, Himanshu Tripathi, Rajeswary Hari* \\ ${ }^{1}$ Department of Biotechnology, Dr.MGR Educational \&Research Institute, University, Maduravoyal, Chennai India.
}

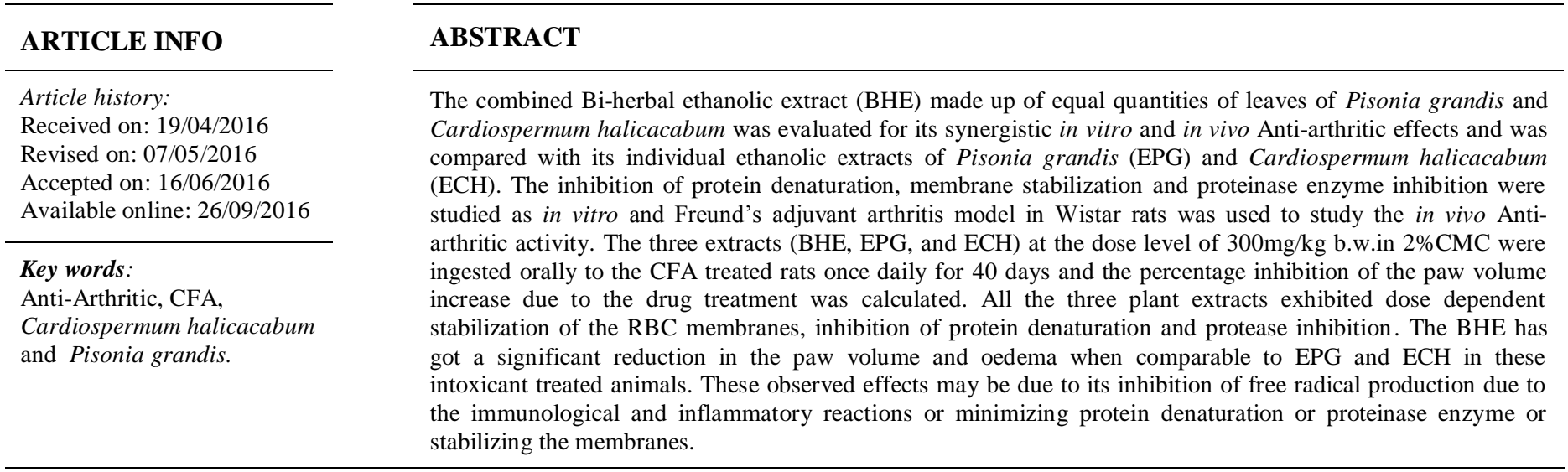

\section{INTRODUCTION}

Rheumatoid arthritis (RA) is a systemic autoimmune multisystem disease characterized by pain, synovial membrane inflammation, peripheral joint inflammation, morning stiffness, destruction of articular tissues and restricted joint movement (Patil et al., 2012; Paval et al., 2009 and Banji et al., 2011). Arthritis can cause severe disability and ultimately affects a person's ability to carry out everyday tasks, restricts the quality of life (Murugananthan et al., 2013). The various proinflammatory molecules including reactive oxygen species, prostaglandins, leukotrines and cytokines released by

\footnotetext{
* Corresponding Author

Dr. Rajeswary Hari, Department of Biotechnology, Dr.MGR

Educational \& Research Institute, University Maduravoyal, Chennai

India.Telephone:09840774705.E-mail: rajihar@gmail.com
}

macrophages are involved in the cause of this disorder (Henderson et al., 1987; Snedegard 1985). The regulation of these mediators secreted by macrophages and other immune cells and modulation of arachidonic acid metabolism by inhibiting enzymes like cox and Lox are the potential target for chronic inflammatory conditions (Tripathy et al., 2010). Even though various categories like immunosuppressants, NSAIDs, steroidal anti-inflammatory drugs are being used till now, they offer only temporary relief and produce severe side effectss including gastrointestinal bleeding renal morbidity and cardiovascular toxicity which limit their utility in the treatment of the disease (Pandey et al., 2010). Consequently, there is a need to develop new long acting anti-inflammatory agents with minimum side effects. Herbal medicine is a form of alternative treatment for several ailments and plant derived drugs are gaining popularity both in developing and developed countries due to their natural origin and less side effects in the last few years. Plant derived secondary metabolites in the plant extracts are the important source of drugs with desired pharmacological activity. 
Although herbal drugs are effective in treatment of various ailments, very often these drugs are unscientifically exploited and/or improperly used. Therefore a detailed pharmacological evaluation and documentation of plants used in local health tradition is needed. Pisonia grandis $\mathrm{R} . \mathrm{Br}$ (Nyctaginaceae) commonly known as 'Leechaikottaikeerai' (Khare, 2007) is distributed throughout India from the Himalayas down to Ceylon. The plant is used traditionally as an antifungal and anti-rheumatic (Kritikar and Basu, 1984). Leaves are useful in chronic rheumatism, wound healing and also used as vegetable (Asimachatterjee et al., 1984; Manogaran, 2002).

Cardiospermum halicacabum (Sapindaceae family) known as the Balloon Plant or Love in a puff, are widely distributed in Asia and Africa. The whole plant of Cardiospermum halicacabum is diaphoretic, diuretic, emetic, emmenagogue, laxative, refrigerant, rubefacient and stomachic (Duke and Ayensu, 1985). It is used in the treatment of rheumatism, nervous diseases, stiffness of the limbs and snakebite (Chopra et al., 2006). A single drug cannot be effective against all types of severe diseases.

Therefore effective formulations have to be developed using indigenous medicinal plants with proper pharmacological experiments and clinical trials. Since the above mentioned two plants have traditional claim for the treatment of Rheumatic arthritis and they were scientifically evaluated for their potency individually, the present investigation is undertaken to evaluate the synergistic in vitro and in vivo anti-arthritic activity of the Biherbal ethanolic extract (BHE) which is prepared using equal quantities of leaves of Pisonia grandis and Cardiospermum halicacabum. The anti- arthritic activity of BHE is compared with the individual ethanolic extract of Pisonia grandis (EPG) and individual ethanolic extract of Cardiospermum halicacabum (ECH).

\section{MATERIALS AND METHODS}

\section{Chemicals}

Ethanol, Bovine Serum Albumin, Acetyl Salicylic Acid were purchased from SD Fine Chemicals Ltd, India. Perchloric acid and Hydrochloric acid were purchased from Thermo Fisher Scientific India Pvt Ltd. Enzyme Trypsin was purchased from SISCO Research Laboratories Pvt Ltd, Mumbai. All other chemicals and reagents used were of analytical grade.

\section{Collection of plant material}

The leaves of Pisonia grandis and Cardiospermum halicacabum were collected from the National Siddha Medical College and Research center India and were authenticated by Dr. Sankaranarayanan, Assistant Director, Dept of Research and Development, of the same college. The voucher specimen is also available in herbarium file of the same center.

\section{Preparation of plant extract}

The leaves of plants Pisonia grandis (100gms) and Cardiospermum halicacabum (100gms) separately and a synergy mix of $100 \mathrm{gms}$ of $P$. grandis and $100 \mathrm{gms}$ of $C$. halicacabum were shade dried and pulverized to a coarse powder. The powder was passed through 40-mesh sieve and exhaustively extracted with $90 \%$ (v/v) (200ml) ethanol by cold maceration process at room temperature for three days. The extract was filtered and the filtrate was evaporated until all the solvent had been removed and further removal of water was carried out by freeze drying to give an extract sample with the yield of $19.6 \%(\mathrm{w} / \mathrm{w})$. Similarly the EPG and ECH were also prepared separately. The EPG extract yield was $9.6 \%(w / w)$ and the ECH sample yield was $8.6 \%(w / w)$. The extracts were stored in refrigerator and used for the future investigation.

\section{Animals}

Adult albino rats of Wistar strain weighing 120 - $175 \mathrm{~g}$ and adult Albino mice were used in the pharmacological and toxicological studies. The inbred animals were taken from animal house in Vel's College of pharmacy Chennai, India. The animals were maintained in well ventilated room temperature with natural $12 \pm 1 \mathrm{~h}$ day-night cycle in the propylene cages. They were fed balanced rodent pellet diet from Poultry Research Station, Nandanam, Chennai, India and tap water ad libitum was provided throughout the experimental period. The animals were sheltered for one week and prior to the experiment they were acclimatized to laboratory temperature. The protocol was approved by Animal Ethics Committee constituted for the purpose as per CPCSEA Guideline.

\section{Acute toxicity studies}

Acute toxicity studies were conducted with BHE, EPG and ECH extracts in adult Albino mice by Staircase method of Ghosh, 1984. Albino mice of either sex were selected and segregated in to 7 groups of 6 animals each. Single dose of BHE, EPG and ECH extracts dissolved in $0.5 \%$ aqueous Tween80, starting from the minimal dose of $50 \mathrm{mg} / \mathrm{kg}$ up to $2000 \mathrm{mg} / \mathrm{kg}$ were administered orally.

The drug treated animals were observed carefully for its toxicity signs and mortality. $\mathrm{LD}_{50}$ doses were selected for the evaluation synergistic anti-arthritic activity. From the maximum dose, $1 / 10^{\text {th }}$ of the concentration was considered as therapeutic dose for further studies. All animals were also further observed for 14 days for clinical symptoms and mortality.

\section{In vitro Anti-Arthritic activity \\ Protein denaturation inhibition study}

The method of protein denaturation was studied as described by Mizushima and Kobayashi, 1968. The reaction mixture contained $0.05 \mathrm{ml}$ of crude ethanolic extracts of BHE, EPG and $\mathrm{ECH}$ at variable concentrations ranging from 50 to $1000 \mu \mathrm{g}$ in $10 \% \mathrm{v} / \mathrm{v}$ of polyethylene glycol and $0.45 \mathrm{ml}$ of bovine serum albumin ( $5 \% \mathrm{w} / \mathrm{w}$ aqueous solution). The $\mathrm{pH}$ was adjusted to 6.3 by adding $0.1 \mathrm{~N} \mathrm{HCl}$ and the samples were incubated at $37{ }^{\circ} \mathrm{C}$ for $20 \mathrm{~min}$ and then heated at $57{ }^{\circ} \mathrm{C}$ for $3 \mathrm{~min}$. After cooling $2.5 \mathrm{ml}$ phosphate buffer saline ( $\mathrm{pH}$ 6.3) was added to each tube. The 
resulting turbidity was measured spectrophotometrically at 660 nm. For control tests $0.05 \mathrm{ml}$ distilled water was used instead of extracts while product control tests lacked bovine serum albumin.

The percentage inhibition of protein denaturation was calculated. The control represents $100 \%$ protein denaturation. The results were compared with acetyl salicylic acid which was used as a positive control in the present investigation.

\section{Membrane stabilization study}

The method of RBC membrane Stabilization was studied as described by Saket et.al., 2010.The total volume $(4.5 \mathrm{ml})$ of reaction mixture contained $2 \mathrm{ml}$ of hypotonic saline $(0.36 \%$ $\mathrm{NaCl}), 1 \mathrm{ml}$ of0.15 $\mathrm{M}$ phosphate buffer ( $\mathrm{pH} 7.4$ ) and $1 \mathrm{ml}$ crude extracts of BHE, EPG and ECH at variable concentrations ranging from 50 to $1000 \mu \mathrm{g}$ in normal saline. To all the test tubes $0.5 \mathrm{ml}$ of $10 \% \mathrm{v} / \mathrm{v}$ rat $\mathrm{RBC}$ in normal saline was added. The mixtures were incubated at $56^{\circ} \mathrm{C}$ for 30 minutes. The tubes were cooled under running tap water for 20 minutes. The mixtures were centrifuged and hemoglobin content in the suspension was estimated using spectrophotometer at $560 \mathrm{~nm}$. For negative control $1.0 \mathrm{ml}$ of isotonic saline was used instead of extracts. Acetyl salicylic acid was used as positive control under the same assay conditions.

Membrane stabilizing potential of the extracts was calculated accordingly from the decrease in absorbance at $560 \mathrm{~nm}$ in comparison with the negative control. Percentage membrane stabilization was calculated.

\section{Proteinase Inhibition study}

The proteinase enzyme inhibitory assay was studied by the method described by Oyedapo et al., 1995. The reaction mixtures $(2.0 \mathrm{ml})$ contained $0.06 \mathrm{mg}$ trypsin, $1.0 \mathrm{ml}$ of $25 \mathrm{mM}$ Tris- $\mathrm{HCl}$ buffer ( $\mathrm{pH} \mathrm{7.4)}$ and $1.0 \mathrm{ml}$ of crude extracts of BHE, EPG and ECH at variable concentrations ranging from 50 to 1000 $\mu \mathrm{g}$ in polyethylene glycol. The above mixtures were incubated at $37^{\circ} \mathrm{C}$ for 5 minutes and then $1.0 \mathrm{ml}$ of $0.8 \%$ (w/v) casein was added.

The mixtures were subjected to an additional 20 minutes of incubation at $37^{\circ} \mathrm{C}$ and $2.0 \mathrm{ml}$ of $70 \%(\mathrm{v} / \mathrm{v})$ perchloric acid was added to terminate the reaction. The cloudy suspension was centrifuged. Absorbance of the supernatant was read at $280 \mathrm{~nm}$ against buffer as blank. The percentage of inhibition was calculated.

\section{Assay of in -Vivo Anti-Arthritic activity}

The anti-arthritic activity was performed according to Jubie et al., 2008 method. Animals were divided into 6 groups of 6 animals each and each group was given dose schedule as follows: Group I: Animals received a suspension of $2 \mathrm{ml} / \mathrm{Kg} \mathrm{CMC} \mathrm{(2 \%} \mathrm{v/v}$ of CMC) p.o., once daily.

This group served as control. Group II, III, IV, V\&VI: Animals received a suspension of $2 \mathrm{ml} / \mathrm{Kg} \mathrm{CMC}$ p.o, and were injected with $0.1 \mathrm{ml}(0.5 \% \mathrm{w} / \mathrm{v})$ of Freund's adjuvant in the right hind foot under the plantar region after $30 \mathrm{mins}$ of CMC administration. Group III, IV and V: Freund's adjuvant treated animals received $200 \mathrm{mg} / \mathrm{Kg}$ body weight of BHE, EPG and $\mathrm{ECH}$ respectively in $2 \mathrm{ml} / \mathrm{Kg}$ of $2 \% \mathrm{CMC}$ p.o, once daily for 40 days. Group VI: Freund's adjuvant treated animals received $45 \mathrm{mg} / \mathrm{Kg}$ body weight of Indomethacin in $2 \mathrm{ml}$ of $2 \% \mathrm{CMC}$ p.o, once daily for 40 days.

The drug treatment was continued with the respective groups for 40 days. Every day animals were carefully and thoroughly inspected by examining the affected paw and animal's general status. The width and height of the paw and the width of the joints were measured with a caliper ruler before the start of the experiment and on $4^{\text {th }}, 13^{\text {th }}, 25^{\text {th }}$ and $40^{\text {th }}$ day after injection of Freund's adjuvant.

The percentage inhibition of the paw volume was calculated by the formula:

$$
\% \text { Inhibition }=(1-(\text { drug treated } / \text { negative control })) * 100
$$

\section{Statistical Analysis}

The values reported are Mean $\pm \mathrm{SD}$. The statistical analysis was carried out using Graph pad prism software for analysis of variance (ANOVA) followed by Dunnet's ' $t$ ' test. The $\mathrm{p}$ values $<0.05$ were considered as significant.

\section{RESULTS}

\section{Acute toxicity studies}

No toxic symptoms were observed after administration of different dose levels of extract up to maximum of $2000 \mathrm{mg} / \mathrm{kg}$ p.o. according to OECD guideline 423. And in addition the higher dose of $5000 \mathrm{mg} / \mathrm{kg}$ dose was administered to a group of animals. But symptoms like dyspnea were identified. Hence the one tenth of safe tolerable dose was used as therapeutic dose for further pharmacological study.

From this experiment the maximum therapeutic dose level of BHE, EPG and ECH extracts were studied as $200 \mathrm{mg} / \mathrm{kg}$.

\section{In vitro Anti-Arthritic activity \\ Inhibition of Protein denaturation}

Anti-arthritic effect of BHE, EPG and ECH were studied significantly by testing various in-vitro parameters. Table-I depicts the inhibition of protein denaturation of different extracts. In the present investigation all the three extracts inhibited the protein denaturation in a dose dependent manner. However, the BHE has got a higher inhibitory percentage of protein denaturation when comparable $(p>0.05)$ to their individual extracts i.e., ECH and EPG.

At the concentrations of 100 and $1000 \mu \mathrm{g} / \mathrm{ml}$, the inhibitory percentage of BHE was significantly comparable to the positive control Acetyl Salicylic acid used in this present investigation. 
Table 1: Effect of BHE, EPG and ECH extracts on inhibition of Protein denaturation .

\begin{tabular}{ccccc}
\hline $\begin{array}{c}\text { Concentration } \\
(\boldsymbol{\mu g} / \mathbf{m l})\end{array}$ & $\begin{array}{c}\text { Inhibitory activity of ECH } \\
(\boldsymbol{\%})\end{array}$ & $\begin{array}{c}\text { Inhibitory activity of EPG } \\
(\boldsymbol{\%})\end{array}$ & $\begin{array}{c}\text { Inhibitory activity of BHE } \\
(\boldsymbol{\%})\end{array}$ & $\begin{array}{c}\text { Inhibitory activity of } \\
\text { Acetyl salicylic acid }(\boldsymbol{\%})\end{array}$ \\
\hline 50 & $2.16 \pm 0.14 \mathrm{a}^{* *}$ & $2.3 \pm 0.45 \mathrm{~b}^{* *}$ & $6.4 \pm 0.25 \mathrm{c}^{\mathrm{ns}}$ & $6.9 \pm 0.32$ \\
100 & $5.8 \pm 0.50 \mathrm{a}^{* *}$ & $6.9 \pm 0.28 \mathrm{~b}^{* *}$ & $16.33 \pm 0.29 \mathrm{c}^{\mathrm{ns}}$ & $13.42 \pm 0.64$ \\
200 & $12.06 \pm 0.31 \mathrm{a}^{* *}$ & $13.06 \pm 0.89 \mathrm{~b}^{* *}$ & $22.39 \pm 0.40 \mathrm{c}^{\mathrm{ns}}$ & $23.78 \pm 0.26$ \\
250 & $14.49 \pm 0.37 \mathrm{a}^{* *}$ & $15.43 \pm 0.48 \mathrm{~b}^{* *}$ & $29.30 \pm 1.74 \mathrm{c}^{\mathrm{ns}}$ & $30.61 \pm 0.25$ \\
500 & $32.41 \pm 0.51 \mathrm{a}^{* *}$ & $29.58 \pm 0.67 \mathrm{~b}^{* *}$ & $57.18 \pm 1.03 \mathrm{c}^{\mathrm{ns}}$ & $46.84 \pm 1.81$ \\
1000 & $60.91 \pm 1.09 \mathrm{a}^{* *}$ & $60.37 \pm 0.73 \mathrm{~b}^{* *}$ & $82.92 \pm 0.93 \mathrm{c}^{\mathrm{ns}}$ & $86.12 \pm 0.21$ \\
\hline
\end{tabular}

Values are expressed in mean \pm SD $(n=3)$, statistical significant test for comparison was done by ANOVA followed by Dunnet's ' $t$ ' test Comparison between a Acetylsalicylic acid vs ECH, b - Acetylsalicylic acid vs EPG and c - Acetylsalicylic acid vs BHE. **p<0.1 and ns - Non-Significant.

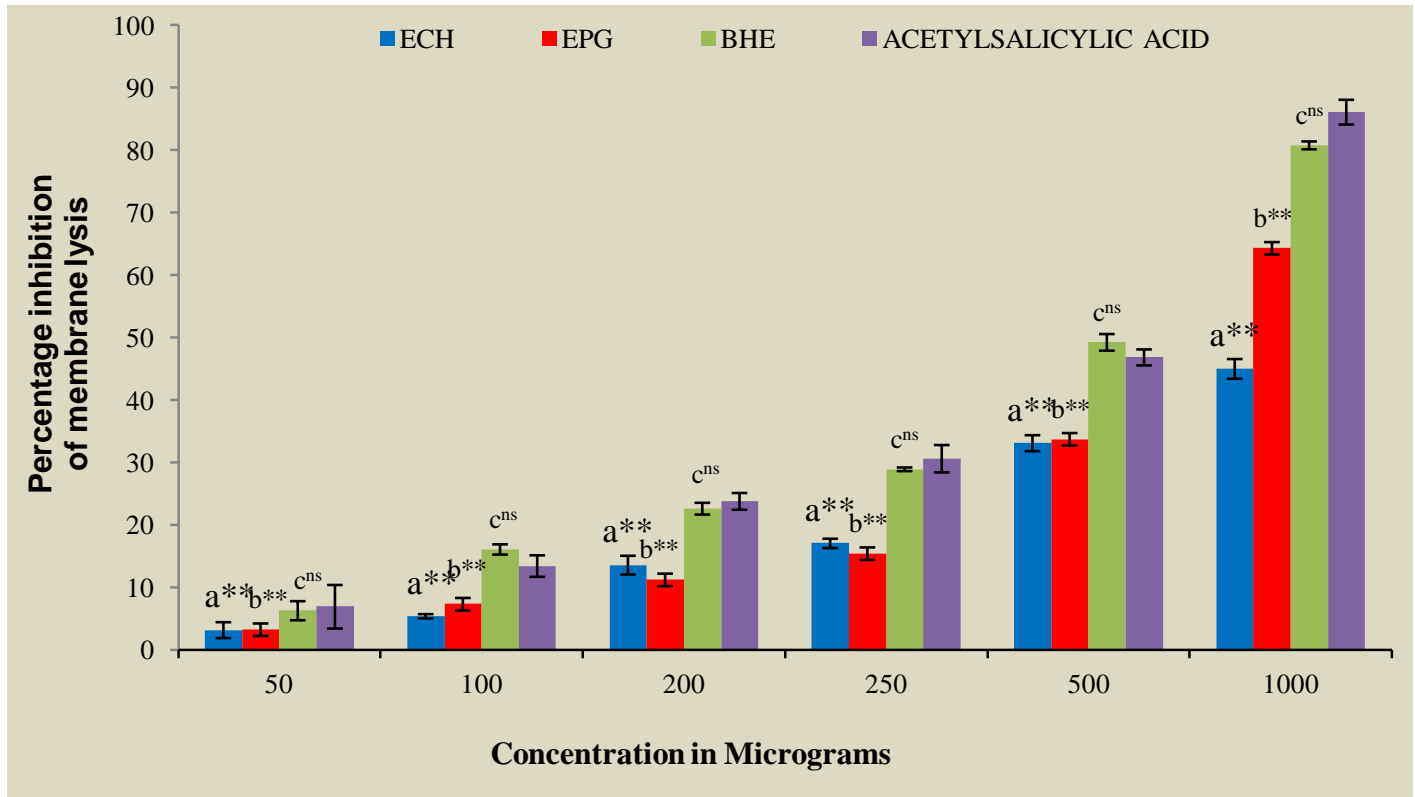

Fig. 1: Membrane stabilization activity of ECG, ECH, BHE extracts and acetyl salicylic acid. Each value represents the mean \pm SD $(n=3)$.Comparison betweena - Acetylsalicylic acid vs ECH, b - Acetylsalicylic acid vs EPG and c - Acetylsalicylic acid vs BHE.*p<0.05, and ns - Non-Significant.

\section{Membrane stabilization study}

The stabilization of RBC membranes by plant extracts against heat and hypotonic saline-induced damage in the present investigation further establishes its anti-inflammatory action. The percentage inhibition of the heat induced hemolysis by ECH, EPG, and BHE were shown in the Figure-I. In the present investigation there was a dose dependent protection of $\mathrm{RBC}$ by all the three extracts. However BHE showed a maximum protection of $80.80 \%$ against lysis at the concentration of $1000 \mu \mathrm{g} / \mathrm{ml}$ against its individual extracts ECH and EPG which showed $45.00 \%$ and $64.31 \%$ protection respectively at the same concentration. It is observed in the study that the BHE exhibited higher protection to the RBC membranes when comparable to the positive control acetyl salicylic acid which is showed $86.12 \%$ inhibition of lysis at the same concentration.

\section{Proteinase Inhibition study}

The proteinase inhibitory activity of the ECH, EPG, and BHE extracts were shown in the Table -II. All the three extracts and the positive control acetyl salicylic acid exhibited a dose dependent anti-proteinase activity. At concentrations of 500 and
$1000 \mu \mathrm{g} / \mathrm{ml}$ the BHE exhibited higher anti-proteinase activity of $59.63 \%$ and $96.72 \%$ respectively when comparable when comparable ( $p>0.05$ ) to the positive control which showed $51.44 \%$ and $85.72 \%$ of anti-proteinase activity at the same concentration.

\section{Assay of in -Vivo Anti-Arthritic activity}

Table-III shows the anti-arthritic activity of BHE, EPG, $\mathrm{ECH}$ and the Indomethacin on complete Freund's adjuvant (CFA) induced arthritis. In the present study at the dose level $200 \mathrm{mg} / \mathrm{kg}$ b.w, all the three ethanol extracts reduced the complete Freund's adjuvant (CFA) induced chronic inflammation in the knee joint of rats as compared with that of the standard drug Indomethacin. There was a significant reduction in the paw volume $(142.30 \mathrm{~mm}$ on $40^{\text {th }}$ day) of the affected Group III rats which received the BHE when comparable $(\mathrm{P}<0.001)$ to the Group IV and Group V rats which received the individual extracts such as EPG and ECH and exhibited the increased paw volume of $155.73 \mathrm{~mm}$ and $152.23 \mathrm{~mm}$ on the same day. The cordial signs of the chronic inflammatory reactions like redness, swelling, arthralgia and immobility of affected joints were significantly less in the drug treated Group III, IV and V animals than those of the Group II CFA treated animals. 
Table 2: Effect of BHE, EPG and ECH extracts on in-vitro model of Protease Inhibition.

\begin{tabular}{ccccc}
$\begin{array}{c}\text { Concentration } \\
(\boldsymbol{\mu} \mathbf{g} \mathbf{m l})\end{array}$ & $\begin{array}{c}\text { Inhibitory activity of ECH } \\
(\boldsymbol{\%})\end{array}$ & $\begin{array}{c}\text { Inhibitory activity ofEPG } \\
(\boldsymbol{\%})\end{array}$ & $\begin{array}{c}\text { Inhibitory activity } \\
\text { of BHE }(\boldsymbol{\%})\end{array}$ & $\begin{array}{c}\text { Inhibitory activity of } \\
\text { Acetyl salicylicacid }(\boldsymbol{\%})\end{array}$ \\
\hline 50 & $16.01 \pm 0.62 \mathrm{a}^{* *}$ & $17.46 \pm 1.23 \mathrm{~b}^{* *}$ & $21.17 \pm 0.56 \mathrm{c}^{\mathrm{ns}}$ & $23.11 \pm 0.62$ \\
100 & $20.49 \pm 0.57 \mathrm{a}^{* *}$ & $16.38 \pm 0.41 \mathrm{~b}^{* *}$ & $24.89 \pm 1.01 \mathrm{c}^{\mathrm{ns}}$ & $27.63 \pm 0.85$ \\
200 & $23.22 \pm 0.78 \mathrm{a}^{* *}$ & $21.71 \pm 0.44 \mathrm{~b}^{* *}$ & $34.11 \pm 2.34 \mathrm{c}^{\mathrm{ns}}$ & $37.20 \pm 1.28$ \\
250 & $38.54 \pm 0.85 \mathrm{a}^{* *}$ & $31.79 \pm 0.57 \mathrm{~b}^{* *}$ & $45.46 \pm 1.99 \mathrm{c}^{*}$ & $40.28 \pm 0.47$ \\
500 & $49.54 \pm 0.40 \mathrm{a}^{* *}$ & $46.06 \pm 2.28 \mathrm{~b}^{* *}$ & $59.63 \pm 1.69 \mathrm{c}^{*}$ & $51.44 \pm 0.27$ \\
1000 & $76.77 \pm 2.95 \mathrm{a}^{* *}$ & $73.7 \pm 1.47 \mathrm{~b}^{* *}$ & $96.72 \pm 3.22 \mathrm{c}^{*}$ & $85.72 \pm 0.88$ \\
\hline
\end{tabular}

Values are expressed in mean $\pm \mathrm{SD}(\mathrm{n}=3)$, statistical significant test for comparison was done by ANOVA followed by Dunnet's ' $\mathrm{t}$ ' test Comparison between a Acetylsalicylic acid vs ECH,b - Acetylsalicylic acid vs EPG and c - Acetylsalicylic acid vs BHE. *p<0.05, **p<0.1 and ns - Non-Significant.

Table 3: Effect of BHE, EPG and ECH extracts on CFA induced chronic immunological Arthritic model.

\begin{tabular}{|c|c|c|c|c|}
\hline \multirow[b]{2}{*}{ Treatment } & \multicolumn{4}{|c|}{ Mean increase in joint diameter in $(\mathrm{mm})$ and Inhibition $(\%)$ on } \\
\hline & 4th day & 13th day & 25th day & 40th day \\
\hline Group I CMC treated (control) & $103.16 \pm 6.16$ & $105.46 \pm 7.52$ & $107.45 \pm 9.01$ & $108.23 \pm 7.86$ \\
\hline Group-II CFA treated & $135.36 \pm 12.19$ & $198.34 \pm 12.95$ & $234.46 \pm 10.52$ & $235.43 \pm 12.99$ \\
\hline Group-III BHE + CFA treated & $\begin{array}{c}106.20 \pm 8.56 \mathrm{a}^{*} \\
(21 \%)\end{array}$ & $\begin{array}{c}149.00 \pm 8.22 \mathrm{a} * * * \\
(24.74 \%)\end{array}$ & $\begin{array}{c}160.26 \pm 7.27 \mathrm{a} * * * \\
(31.64 \%)\end{array}$ & $\begin{array}{c}142.30 \pm 7.00 \mathrm{a}^{* * * *} \\
(35.76 \%)\end{array}$ \\
\hline Group-IV EPG + CFA treated & $\begin{array}{c}125.30 \pm 18.87 b^{*} \\
(7.4 \%)\end{array}$ & $\begin{array}{c}187.86 \pm 8.56 b^{*} \\
(5.2 \%)\end{array}$ & $\begin{array}{c}195.33 \pm 13.29 \mathrm{~b}^{* * * *} \\
(15.91 \%)\end{array}$ & $\begin{array}{c}155.73 \pm 17.03 \mathrm{~b}^{* * *} \\
(33.85 \%)\end{array}$ \\
\hline Group-V ECH + CFA treated & $\begin{array}{c}127.70 \pm 7.66 \mathrm{c}^{*} \\
(5.6 \%)\end{array}$ & $\begin{array}{c}184.03 \pm 5.98 \mathrm{c}^{*} \\
\quad(7.21 \%)\end{array}$ & $\begin{array}{c}197.15 \pm 9.12 \mathrm{c}^{* * *} \\
(15.91 \%)\end{array}$ & $\begin{array}{c}152.23 \pm 14.43 \mathrm{c}^{* * *} \\
(35.33 \%)\end{array}$ \\
\hline Group VI Indomethacin + CFA treated & $\begin{array}{c}116.83 \pm 8.37 \mathrm{~d}^{* *} \\
(7.2 \%)\end{array}$ & $\begin{array}{c}175.83 \pm 7.41 \mathrm{~d}^{* * * *} \\
(6.47 \%)\end{array}$ & $\begin{array}{c}140.66 \pm 6.68 \mathrm{~d}^{* * * *} \\
(37.29 \%)\end{array}$ & $\begin{array}{c}132 \pm 8.87 \mathrm{~d}^{* * * *} \\
(41.33 \%)\end{array}$ \\
\hline
\end{tabular}

Values are mean \pm SD from 6 animals in each group. Statistical significant test for comparison was done by ANOVA, followed by Dunnet's 't' test.Comparison between a - Group II vs Group III, b - Group II vs Group IV, c - Group II vs Group V, d - Group II vs Group VI. P Values: $*<0.05$, $* *<0.01, * * *<0.001$, ns non significant.

\section{DISCUSSION}

Rheumatoid Arthritis is a common autoimmune disorder, characterized by synovial proliferation, inflammation followed by destruction and deformity of joints or destruction of cartilage and bone(Mowat,1972). The immunologically mediated CFA induced arthritic model is considered as one of the outstanding animal model of RA which produces polyarthritis with features that look like RA in human (Pathak et al., 2009).The analysis of paw swelling is a simple, sensitive and quick procedure for evaluating the degree of inflammation and consequently the immunological reaction. The immune mediated chronic inflammation involves the release of pro inflammatory cytokines, mainly tumor necrosis factor- $\alpha$ (TNF- $\alpha$ ), interleukin-1 $\beta$ (IL-1 $\beta)$, and IL-6 produced by monocytes, macrophages, and synovial fibroblasts. These mediators are responsible for the pain, destruction of bone and cartilage that can lead to severe disability (Lam et al. 2004). All the steroidal and non-steroidal anti-inflammatory drugs currently available are probably poly component in that they are able to modulate more than one mediator or cellular event concerned with the inflammatory response associated with RA (Whitehouse, 1974). But gastrointestinal bleeding and ulceration is found to be the common side effect for most of the drugs. In recent years, the search for new phytochemical bioactive components from medicinal plants possessing anti-inflammatory properties has been on the rise due to their potential use in the therapy of various chronic and inflammatory mediated conditions.

In the present investigation all three plant extracts BHE, EPG and ECH have significant in vitro and in vivo anti-arthritic
BHE, EPG and ECH were investigated using inhibition of protein denaturation, membrane stabilization and proteinase inhibition. In the present investigation all the three extracts inhibited the protein denaturation in a dose dependent manner. However, the BHE which is made up Pisonia grandis and Cardiospermum halicacabum has got a higher inhibitory percentage of protein denaturation when comparable to their individual extracts. According to Brown and Mackey1968, production of autoantigens in certain rheumatic diseases may be due to in vivo denaturation of proteins. This denaturation probably is associated with the alteration in electrostatic, hydrogen, hydrophobic and disulphide bonding (Grant et al., 1970). The presence of various chemical components in the plants, Pisonia grandis, Cardiospermum halicacabum and their combination such as, carbohydrates, phytosterol, tannins, phenol, flavonoids, glycosides, cardiac glycosides, terpenes, and lignin may be responsible for the inhibition of the protein denaturation. It is generally accepted that a cumulative synergistic relationship among the phyto chemicals are responsible for the overall beneficial medicinal value of plants. These bioactive substances may either control the production of auto antigens or protect the proteins from denaturation observed in the rheumatic diseases.

The principle involved in membrane stabilization is stabilization of human red blood cell membrane by heat and hypo tonicity induced membrane lysis. During the process of inflammation the release of lysosomal enzymes such as cyclooxygenase which is responsible for the conversion of arachidonic acid to prostaglandins $\mathrm{G} 2$ to $\mathrm{PGH} 2$ along with peroxidation that is associated with opening of the long channels 
in the membranes with the release of chemical mediators. The extra cellular activity of these enzymes is said to be related to acute and chronic inflammation. As stated by Oyedapo and Famurewa 1995, the membrane of RBC is structurally similar to the lysosomal membrane and the effect of any substance on stabilization of RBC membrane may be extrapolated to the stabilization of lysosomal membrane. In the present investigation our plant extracts were able to inhibit the heat induced hemolysis effectively thereby stabilizes the RBC membranes. The similar effect may be expected in stabilizing the lysosomal membranes and inhibiting the release of lysosomal content of neutrophils at the site of inflammation in the in vivo condition. Deepan et al.,2012 include alkaloids, carbohydrates, proteins, saponins lignin, steroids, cardiac glycosides found in small quantities in the Cardiospermum halicacabum extracts, and Pisonia grandis reveals that the presence of steroids likes octocosanol, betositosterol, alphaspinosterol, dulcitol and flavonoids in the leaves of the plant (Khare ,2007).Flavonoids and steroids show remarkable anti-inflamatory activity by inhibiting the cox and lox systems (Robert et al., 2001; Tapas et al., 2006).

Proteinases have been implicated in arthritic reactions. Neutrophils are known to be a source of proteinase which carries in their lysosomal granules many serine proteinases. It was previously reported that leukocytes proteinase play important role in the development of tissue damage during in inflammatory reactions and significant level of protection was provided by proteinase inhibitors (Das and Chatterjee, 1995).Our plant extracts considerably inhibited the proteinase enzyme. The presence of cardiac glycosides, flavonoids and saponins in Cardiospermum halicacabum and numerous bio active compounds such as Pinnatol, Allantoin, $\beta$-Sitosterol, $\alpha$-Spinasterol, $\beta$-Sitosterol glucoside, Octocosanal, Dulcitol, Flavonoids and Quercetin in Pisonia grandis extract have the potential to reduce of pain and swelling caused due to inflammation (Elumalai et al., 2012).

Freund's complete adjuvant (FCA)-induced arthritis is been extensively used to study the pathogenesis of rheumatoid arthritis for therapeutics testing (Mizushima et al., 1972 ).

In adjuvant induced arthritis model, rats develop a chronic swelling in multiple joints with influence of inflammatory cells, erosion of joint cartilage and bone destruction and remodeling. These inflammatory changes ultimately result in the complete destruction of joint integrity and function in the affected animals. Freund's adjuvant - induced (CFA) is considered as cell mediated autoimmunity due to the structural mimicry between mycobacteria and cartilage proteoglycans in rats. In the present investigation reduction of paw swelling in the drug treated rats from the third week onwards may be due to immunological protection rendered by the plant extract. Adjuvant inoculation triggers the production of activated macrophages and lymphocytes or their products like monokines, cytokines, chemokines. These in turn produce lipid peroxides due to abnormal lipid peroxidation leading to increased inflammation. In the present investigation a significant reduction in the inflammation was shown in Group III BHE treated animals when compared to that of Group II toxin intoxicated animals indicating the antiperoxidative nature of the plant extract. Observing the in vitro experiments such as inhibition of protein denaturation, membrane stabilization and proteinase inhibition by the plant extracts and in vivo anti-arthritic effect analysis indicates proof towards the above theory of joint preservation. It has also been reported that the flavonoids significantly inhibit the leukocyte migration in a dose dependant manner (Nanrendhirakannan et al., 2007). The high presence of flavonoids in Cardiospermum halicacabum extract indicates the presence of Luteolin which is a common flavanoid with potent anti-inflammatory activity (Johnson et al., 2008), and a flavonoid glycoside, 4-0-methyl-5'-0-actylmyricelin 3-o-gluco(2 to 1) rhamnoside have been isolated from methanolic extract of the leaves of plant Pisonia grandis (Manogaran, 2002) may be responsible for the anti arthritic activity observed in present study.

\section{CONCLUSION}

On the basis of above results, it could be concluded that BHE, a combination of two herbal plants exert a significant Antiarthritic and Anti-inflammatory effects due to different types of active principles each with a single or a diverse range of biological activities, which serves as a good adjuvant in the present armamentarium of these pathological conditions. Further clinical studies are needed to establish its safety and usefulness medically.

\section{Financial support and sponsorship: Nil.}

Conflict of Interests: There are no conflicts of interest.

\section{REFERENCES}

Asimachatterjee, Satyesh Chandra Prakashi. 1984. The Treatise an Indian Medicinal Plants. National institute of science communication, CSIR, New Delhi. pp/ 114.

Banji D, Pinnapureddy J, Banji OJF, Kumar AR, Reddy KN. Evaluation of the concomitant use of methotrexate and curcumin on Freund's complete adjuvant-induced arthritis and haematological indices in rats. Indian J Pharmacol ,2011; 43:546-50.

Brown JH, Mackey HK. Inhibition of heat-induced denaturation of serum proteins by mixtures of non-steroidal anti-inflammatory agents and amino acids, Proc SocExpBiolMed, 1968; 128:225.

Chopra RN, Nayar SL, Chopra IC. Cardiospermum halicacabum and its medicinal properties. Glossary of Indian Medicinal Plants. 2006; 20(3):701-732.

Das SN, Chatterjee S. Long term toxicity study of ART-400. Ind Indg Med, 1995 ;16(2):117- 23.

Deepan T, Alekhya V, Saravanakumar P, Dhanaraju MD. Phytochemical and Anti-Microbial Studies on the Leaves Extracts of Cardiospermum halicacabum Linn. Adv. Biol. Res, 2012; 6(1):14-18.

Duke JA, Ayensu ES. Medicinal plants of China. China: Reference Publications, Inc; 1985.

Elumalai A, Chinna Eswaraiah M, Habibur Rahman. Pisonia grandis $\mathrm{R} . \mathrm{Br}$ - a medicinal plant a review. International Journal of Pharma \& Bio Sciences, 2012; 3(1):76-80.

Ghosh MN. 1984. Fundamentals of Experimental Pharmacology. Scientific Book Agency, Calcutta. pp. 156-157.

Grant NH, Alburn HE, Kryzanauskas C. Stabilisation of serum albumin by anti-inflammatory drugs. Biochem Pharmacol, 1970 ; 19:71522.

Henderson B, Pettipher ER, Higgs GA. Mediators of rheumatoid arthritis. The British Medical Bulletin, 1987; 43(2): 415-428. 
Johnson, Kelley KW, Johnson RW. Luteolin reduces IL-6 production in microglia by inhibiting JNK phosphorylation and activation of AP-1. Proc. Natl. Acad. Sci, 2008; 105 (21): 7534-9.

Jubie S, Jawahar N, Koshy R, Gowramma B, Murugan V, Suresh B. Anti-arthritic activity of bark extracts of Alangium salviifolium Wang. Rasayan J Chem,2008; 1(3):433-36.

Khare CP. 2007. Indian Medicinal Plants. Springer publications Pvt Ltd, New Delhi: pp.502- 503,

Kritikar KR, Basu BD. 1984. Indian Medicinal plants. International book distributors book sellers \& publishers, Dehradun. Vol II: $1561-1564$.

Lam FF, Wong HH, Ethel SK. Time course and substance P effects on the vascular and morphological changes in adjuvant induced monoarthritic rats. Int.Immuno Pharmacol, 2004 ;4: 299- 310.

ManogaranE. Phytochemical and pharmacological activity of PisoniamorindifoliaLinn National symposium on emerging trends in Indian medicinal plants , $2003 ; 746$.

Mizushima Y, Kobayashi M. Interaction of anti-inflammatory drugs with serum proteins especially with some biologically active proteins. J Pharm Pharmacol, 1968 ; 20:169-73.

Mizushima Y, Tsukada W, Akimoto T. A modification of rat adjuvant arthritis for testing antirheumatic drugs. J Pharm Pharmacol, $1972 ; 24: 781-5$.

Mowat AG. Hematologic abnormalities in Rheumatoid arthritis. Sem. Arthr. Rheum, 1971; 1(3): 195-219.

Murugananthan G, Kumar SG, Sathya CP, Mohan S. Antiarthritic and anti-inflammatory constituents from medicinal plants. J App Pharm Sci, 2013; 3:161-4.

Nanrendhirakannan RT, Subramanian S, Kandaswamy M. Anti inflammatory and lysosomal stability actions of Cleome gynandra $\mathrm{L}$. studied in adjuvant induced arthritic rats. Food.chem. Toxicol, 2007; 45:1001-1012.

Oyedapo, Famurewa AJ. Anti-protease and membrane stabilizing activities of extracts of Fagrazanthoxiloides, Olaxsubscorpioides and Tetrapleuratetraptera. Int J. pharmacogn, 1995; 33:65-9.

Pathak N, Gohil P, Patel NB, Kasture S, Jivani N, Bhalodia Y. Curative Effect of Albizia lebbeck methanolic extract against adjuvant arthritis-With special reference to bone erosion. Int J Pharm Sci Drug Res, 2009; 1(1):183-7.

Patil MVK, Kandhare AD, Bhise SD. Anti-arthritic and antiinflammatory activity of Xanthium strumarium L. ethanolic extract in Freund's complete adjuvant induced arthritis. Biomed Aging Pathol, 2012;2:6-15.
Paval J, Kaitheri SK, Potu BK, Govindan S, Kumar RS, Narayanan SN, et al. Anti-arthritic potential of the plant Justicia gendarussa Burm F. Clinics, 2009;64:357-62.

Robert J, Nijveldt, Elsvan Nood, Danny EC, van Hoorn. Flavonoids: A review of probable mechanisms of action and potential applications, Am J Clin Nutr, $2001: 74 ; 418-25$.

Sakat S, Juvekar AR, Gambhire MN. In vitro antioxidant and anti-inflammatory activity of methanol extract of Oxalis corniculato Linn. Inter. J. Pharma Parmacol Sci, 2010;2(1):146-55.

Sankari G, Mounnissamy VM, and Balu V. Evaluation of antiinflammatory and membrane stabilizing properties of ethanolic extracts of Diptheracanthusprostatus(Acanthaceae), Amala Research Bulletin, 2009: $29 ; 188-89$.

Shivanand Pandey. Various techniques for the evaluation of anti arthritic activity in animal models. J. Adv. Pharm. Tech. Res, 2010; 1(2).

Snedegard G. Mediators of vascular permeability in inflammation. Progress in Applied Microcirculation, 1985 7: 96-112.

Tapas AR, Sakarkar DM, Kakde RB, Flavonoids as Nutraceuticals: A Review,Trop. J. Pharma. Res, 2008; 7 (3): 1089-1099.

Tripathy S, Pradhan D, Anjana M. Antiinflammatory and antiarthritic potential of Ammania bacciferalinn. Inter. $\mathrm{J}$ of Pharma and Bio Sci, 2010;1(2):

Whitehouse MW. 1974. ntroduction and background to the regulation of inflammation and the immune response. In: Scherrer RA and Whitehouse MW, (Eds.), Anti-Inflammator Agents: Chemistry and Pharmacology, Academic Press, New York. pp. 2:12.

\section{How to cite this article:}

Padmini N, Sundaramoorthy SD, Tripathi H, Hari R. In vitro and In vivo Anti-Arthritic Activity of Combined Ethanolic Extracts of Pisonia Grandisandcardiospermum halicacabum in Wistar Rats. J App Pharm Sci, 2016; 6 (09): 102-108. 